\title{
Impact of storage condition on postharvest preservation of fresh Bambusa sp.
} shoot

\author{
${ }^{1}$ Changchai, S., ${ }^{1}$ Sumrit, T., ${ }^{2}$ Kitpot, T. and ${ }^{1, *}$ Inrirai, P. \\ ${ }^{1}$ Agricultural and Food Engineering, Faculty of Food and Agricultural Technology, Pibulsongkram \\ Rajabhat University, Phitsanulok, Thailand \\ ${ }^{2}$ Agro-Industrial Product Development, Faculty of Food and Agricultural Technology, Pibulsongkram \\ Rajabhat University, Phitsanulok, Thailand
}

\section{Article history:}

Received: 14 June 2019

Received in revised form: 13 July 2019

Accepted: 15 July 2019

Available Online: 30 July 2019

\section{Keywords:}

Bamboo shoot,

Postharvest senescence,

Quality,

Shelf life

DOI:

https://doi.org/10.26656/fr.2017.4(1).225

\begin{abstract}
This research was aimed to study postharvest senescence of fresh Bambusa sp. shoot. The harvested bamboo shoots were packed in linear low-density polyethylene (LLDPE, 0.07 $\mathrm{mm}$ thick) bag and stored in 2 conditions: ambient $\left(29 \pm 3^{\circ} \mathrm{C}\right)$ and refrigerated temperatures $\left(5 \pm 3^{\circ} \mathrm{C}\right)$. The physical and chemical properties during the 7 days storage were investigated for postharvest quality management. The storage of the bamboo shoots at ambient greatly affected the physical and chemical properties (weight loss, discoloration, reducing sugar content and total acidity content) compared to the refrigerated storage. Under the ambient storage, critical weight loss of shoots (approximately 5) was recorded at day 4 storage along with the darkening of the basal section. Moreover, the reducing sugar rapidly decreased to $50 \%$ of the initial at day 2 storage. Sensory evaluation was conducted, and consumers were able to accept bamboo shoots stored at ambient up to one day of storage. On the other hand, bamboo shoots stored in refrigerated up to 7 days were acceptable. This is due to the quick change of color and odor of the bamboo shoots which can be the quality indicators of the harvested shoots.
\end{abstract}

\section{Introduction}

Bamboo, a plant of the family Poaceae and subfamily Bambuseae, is the longest grass in the world (Shukla et al., 2012; Sindhal et al., 2013). Among over 1,439 described species in 116 genera bamboo in the world (Clark, 2012), Thailand has contributed more than 13 species belonging to $80-90$ genera (Mahayotpanya and Phoungchandang, 2015). Bamboo is recognized as an important natural resource for the paper industry, traditional handicraft, medicine and food business. Bambusa sp. species are selected species from Bambusa burmanica Gamble by seeding. The maximum height of this species is $7-12 \mathrm{~m}$. In one kilogram of fresh weight, there are 4-5 harvested shoots from the mature bamboo shoot. Phuanchik et al. (2015) recommended that Bambusa sp. shoot should use in food business rather than wood industry because of its typical flavor and texture. Sindhal et al. (2013) revealed that the shoot was the ideal food because of low fat, high dietary fiber and rich in mineral content. This was in an agreement with Sood et al. (2017) who studied the quality-related attributes of four species of bamboo shoots (Phyllostachys pubescens, Dendrocalamus asper, Dendrocalamus hemilltoni and Bambusa bambos).
Kusalaruk and Limsangouan (2015) also reported that Bambusa burmanica Gamble shoot contained about 91$92 \%$ moisture content, $0.06 \%$ fat, $2.23-2.60 \%$ dietary fiber and $3.44 \%$ protein including 18 amino acids.

Although the previous research showed the benefit of the bamboo shoots for consumption, cyanide, a dangerous compound, is still being a problem for consuming fresh bamboo. It was found that the average cyanide contents in general bamboo shoots were $167 \mathrm{mg} /$ $\mathrm{kg}$ (Teerapapthamkul et al., 2011). The low content of cyanide was found in Bambusa sp., only $0.22 \mathrm{mg} / \mathrm{kg}$ tested by The Industrial Metrology and Testing Service Centre, Thailand Institute of Scientific and Technological Research, Thailand. The market price of Bambusa sp. shoot in Thailand is 60-90 Baht/ $\mathrm{kg}$ (2-3 US dollars). The distinctive point of the Bambusa sp. shoot that makes this shoot more popular than the other shoot was its typical flavor, sweet taste, not nasty and can be consumed in fresh condition. However, the shelf life of bamboo shoots is limited due to deterioration of qualityrelated attributes from the postharvest procedure. There was various research that studied about the deterioration of various bamboo shoots (Kleinhenz et al., 2000; Lu and Xu, 2004; Shen et al., 2006; Zhou et al., 2012). The 
studies were revealed that the shelf life of bamboo shoot at ambient temperature in open storage and non-MAP (modified atmosphere packaging) condition was only 1 day caused by color changed and sweetness decreased. The suggestive solution that could extend its shelf life was stored in low-temperature condition or suitable MAP condition. However, so far there were no studies conducted on quality-related attributes of Bambusa sp. shoot after postharvest. Therefore, the purpose of this research was to study the physical and chemical changes of the fresh-cut Bambusa sp. shoot during storage for postharvest quality management.

\section{Materials and methods}

\subsection{Materials}

Fresh bamboo shoots of Bambusa sp. were obtained from a commercial bamboo farm in Phitsanulok province, Thailand. Shoots were harvested in the morning and transported at an ambient temperature $\left(29 \pm 3^{\circ} \mathrm{C}\right)$ to the laboratory within an hour. Before conducting analysis, $2 \mathrm{~cm}$ of basal shoots were cut for adjusting the basal surface. All shoot sample were washed by water and dried. Then, the shoot samples were selected on criterions as follow: $0.30-0.80 \mathrm{~kg}$ of weight, $15-20 \mathrm{~cm}$ of length and 3-4 $\mathrm{cm}$ basal of diameter.

\subsection{Packaging and storage temperature}

The bamboo shoot samples were divided into two treatment: (1) stored in LLDPE bags at $29 \pm 3^{\circ} \mathrm{C}, 60 \%$ relative humidity; (2) stored in LLDPE bags at $5 \pm 3^{\circ} \mathrm{C}$, $80 \%$ relative humidity. Experimental periods were 7 days. The size of the bag was $25 \mathrm{~cm}$ x $38 \mathrm{~cm}, 0.07 \mathrm{~mm}$ in thick and has 12 holes ( $5 \mathrm{~mm}$ diameter size).

\subsection{Physical properties}

\subsubsection{Color measurement}

The color change of the basal and middle of the shoot was measured using Chroma Meters (Model CR400, Konica Minolta, INC.) in terms of CIE L* (lightness), $\mathrm{a}^{*}$ (redness and greenness) and $\mathrm{b}^{*}$ (yellowness and blueness). The color of the same samples was measured every day. The color value was obtained by the meters and expressed as L* (lightness), $\mathrm{h}$ (hue angle) and $\mathrm{C}^{*}$ (chroma) values. Hue angle and chroma were calculated using the following formula.

$$
\begin{aligned}
& \text { Hue angle }(\mathrm{h})=\tan ^{-1}\left(\mathrm{~b}^{*} / \mathrm{a}^{*}\right) \\
& \text { Chroma }\left(\mathrm{C}^{*}\right)=\left(\mathrm{a}^{* 2}+\mathrm{b}^{* 2}\right)^{1 / 2}
\end{aligned}
$$

\subsubsection{Weight loss}

For determining weight loss during storage, five shoots in each treatment were numbered. Weight of each shoot was measured with precision balance (model
ME3002E, Mettler Toledo) having least count of 0.001 g. The loss in weight was expressed as percentage of the original fresh weight.

\subsubsection{Texture analysis}

The firmness of shoot samples was measured using a texture analyzer (Model CT3-100, Brookfield Engineering Laboratories, MA) equipped with a $2 \mathrm{~mm}$ stainless steel cylinder probe. The firmness was conducted on the basal and middle section of each peeled shoot. The penetration speed of $2 \mathrm{~mm} / \mathrm{s}$ was set to determine 50 percentage deformation. The averages of firmness were expressed in force $(\mathrm{N})$

\subsection{Chemical properties}

\subsubsection{Total acidity}

Total acidity was measured using titration method. In each treatment, the peel shoot was chopped, crushed and filtered. A total of $2 \mathrm{~mL}$ of filtrate was placed in a volumetric flask, and 2-3 drops of phenolphthalein solution (Merck, Germany) was added. The solution was titrated with $0.01 \mathrm{~N}$ sodium hydroxide $(\mathrm{NaOH}, \mathrm{RCI}$ Labscan, Thailand) to a pink end point. The total acid was expressed as percentage of the initial sample solution. Measurement of total acidity was repeated for three experimental replicates of each treatment.

\subsubsection{Sugar content}

Sugar content in shoot samples was determined using a colorimetric method by UV/Vis Spectrophotometer (AOAC, 2000). The solution from crushed and filtered the shoot was diluted with deionized water. The $2 \mathrm{~mL}$ of diluted sample was placed in a tube, and $2 \mathrm{~mL}$ of $6 \mathrm{M}$ hydrochloric ( $\mathrm{HCl}$, GAMMACO, Thailand) was added. Placed the sample in boiling water for 10 mins after that, $8 \mathrm{~mL}$ of $2.5 \mathrm{M} \mathrm{NaOH}$ and $2 \mathrm{~mL}$ of 0.05 M 3,5-Dinitrosalicylic acid solution (DNSA, Merck, Germany) were added. The sample tube was covered by Parafilm (Bemis, USA) and placed in boiling water for 5 mins followed by ice water for 10 mins. The mins of the sample was measured with a UV-Spectrophotometer (Model Evolution 201, Thermo Scientific, US) at 580 $\mathrm{nm}$, using blank as control. The sugar content of the sample was interpolated from the standard curve and expressed as $\mathrm{g} / \mathrm{L}$.

\subsubsection{Proximate analysis}

Proximate composition was measured by AOAC method (AOAC, 2000). The proximate composition was determined after 4, and 7 days of storage period. Moisture content was expressed as percentage of wet basis. The protein, fat, fiber, carbohydrate and ash were expressed as percentage of dry basis. 


\subsection{Sensory evaluation}

The consumer acceptance test from the sensory evaluation was performed every day by consumers $(n=50)$ who were non-smokers and consume bamboo shoot at least once a week. The shoot samples were presented individually in plastic container. The shoot samples were codded with 3-digit random numbers. Overall liking, appearance, color and odor based on a 9point hedonic scale $(1=$ dislike extremely, $5=$ neither like nor dislike, and $9=$ like extremely) were evaluated (Peryam and Pilgrim, 1957).

\subsection{Data analysis}

All data (with three replicates) were statistically analyzed by analysis of variance (ANOVA) using SPSS version 16.0 (SPSS Inc., Chicago, IL) to examine significant differences of the evaluated properties. Duncan's multiple range test (DMRT) was applied for multiple comparisons. The significant level of ANOVA and DMRT was justified at p-value lower than 0.05 .

\section{Results and discussion}

\subsection{Color measurement}

Color of bamboo shoots changed during storage temperature and storage time. The shoot appearance in different storage temperature is presented in Table 1. For the ambient condition, brownish-black spots were detected on shoots after 3 days of storage and developed into the dark in 4 days storage. This result was in an agreement with Nugrahedi et al. (2004) who reported that shoots started to discolor within 1 day and after 3 days was brown-black. Whereas shoot sample that kept at $5 \pm 3^{\circ} \mathrm{C}$ had only a few yellow stains on the basal section after 7 days of storage. The values of $L^{*}, h$ and $\mathrm{C}^{*}$ during storage condition are presented in Table 2 . and Table 3. However, we found similar pattern of discoloration of the basal section; the $\mathrm{L}^{*}$ and $\mathrm{h}$ value of 3 days storage was significantly different $(p<0.05)$ from the control sample. For 7 days storage in refrigerated condition, $L^{*}$ value was significantly different $(\mathrm{p}<0.05)$ from the first day $(83.27 \pm 1.75)$, then it slightly decreased to $77.49 \pm 2.19$ on the last day of storage. For the shade (h) of bamboo shoots, it was not significantly different ( $>0.05$ ). This result was in agreement with Kleinhenz et al. (2000) who found that shoots stored at $8^{\circ} \mathrm{C}$ had discoloration after 6 days of storage where the basal surface was turned into yellow. The discoloration in bamboo shoots occurred due to enzymatic browning. Phenylalanine ammonia lyase and peroxidase were activated from tissue injury due to postharvest (Chen et al.,1989; Nugrahedi et al., 2004). Moreover, it was found that the middle section shoot color did not change during the storage period because those enzymes were not activated. To inhibit the formation of the activity of peroxidase and phenylalanin ammonialyas, Shen et al. (2006) reported to apply modified atmosphere packaging (MAP) treatment that the gas components were $2 \% \mathrm{O}_{2}$, $5 \% \mathrm{CO}_{2}$ and $93 \% \mathrm{~N}_{2}$, so, the shoot browned slightly and remained edible.

\subsection{Weight loss}

The percentage of relative fresh weight of bamboo shoot samples are presented in Figure 1. Weight loss at ambient condition sample was higher than refrigerated condition. The weight loss percentage of sample kept in ambient condition increased from $1.70 \pm 0.42$ to $8.19 \pm 1.47$ while another sample increased from $1.03 \pm 0.33$ to $2.79 \pm 0.45$. Kleinhenz et al. (2000) reported that shoots which had lost more than $5 \%$ were visually rated unacceptable. From this study, the weight loss percentage of the ambient condition at 4 days storage, was approximately $5 \%$, so it can be concluded that this sample was visually unacceptable after 4 days of storage. The relative humidity also affected to weight loss due to the differences in relative humidity and vapor pressure gradients between shoots and air which were affected to water loss from shoots. For reduction percentage of weight loss suggest using the suitable packaging material that minimized condensation within the package (Kleinhenz et al., 2000).

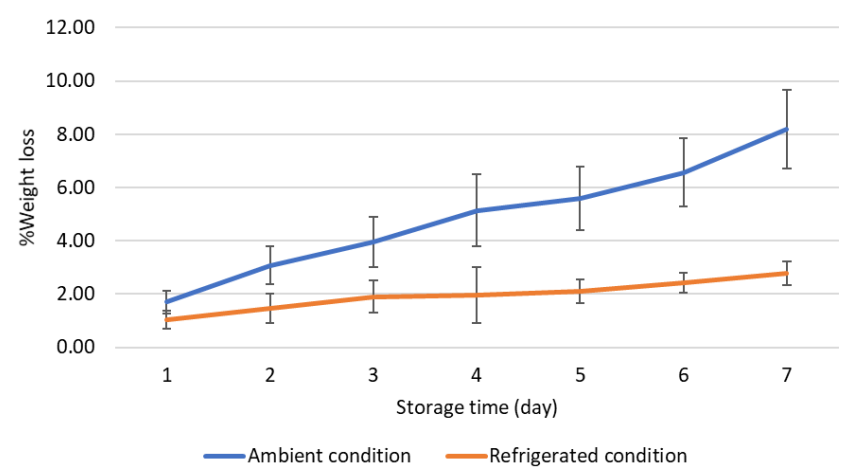

Figure 1. Weight loss of bamboo shoot was stored in LLDPE bag that affected by storage temperature

\subsection{Firmness}

The firmness of basal and middle fresh bamboo shoots kept in different storage conditions are presented in Table 4. The basal section had more firmness than the middle section in all condition due to the accumulation of cellulose and lignin in the basal section. It was found that the firmness of ambient samples was significantly increased after day 2 and 3 ( $\mathrm{p}<0.05)$. Xu et al. (2004) reported that lignin content increased $15.8 \%$ in the basal section during storage while it decreased in the middle section of shoot. These results suggested that the lignifying process take place in the basal section. Meanwhile, the firmness of the basal section of the 
Table 1. Appearance of shoot during storage in each treatment

\begin{tabular}{cccccc}
\hline $\begin{array}{c}\text { Storage } \\
\text { Time (Day) }\end{array}$ & $\begin{array}{c}\text { Ambient } \\
\text { Condition }\end{array}$ & $\begin{array}{c}\text { Refrigerated } \\
\text { Condition }\end{array}$ & $\begin{array}{c}\text { Storage } \\
\text { Time (Day) }\end{array}$ & $\begin{array}{c}\text { Ambient } \\
\text { Condition }\end{array}$ & $\begin{array}{c}\text { Refrigerated } \\
\text { Condition }\end{array}$ \\
\hline 1 & & & & & \\
\hline
\end{tabular}

Table 2. color value of the basal section during storage in each treatment

\begin{tabular}{cccc}
\hline Treatment & $\mathrm{L}^{*}$ & $\mathrm{~h}$ & $\mathrm{C}^{*}$ \\
\hline Control & $83.27 \pm 1.75^{\mathrm{a}}$ & $86.63 \pm 3.37^{\mathrm{a}}$ & $13.83 \pm 1.46^{\mathrm{d}}$ \\
AC day 2 & $77.90 \pm 2.28^{\mathrm{ab}}$ & $83.14 \pm 0.51^{\mathrm{ab}}$ & $23.00 \pm 1.57^{\mathrm{b}}$ \\
AC day 3 & $71.61 \pm 6.67^{\mathrm{c}}$ & $80.02 \pm 3.84^{\mathrm{bc}}$ & $29.39 \pm 1.47^{\mathrm{a}}$ \\
$\mathrm{AC}$ day 4 & $65.35 \pm 4.24^{\mathrm{d}}$ & $76.56 \pm 2.20^{\mathrm{c}}$ & $31.61 \pm 2.82^{\mathrm{a}}$ \\
$\mathrm{RC}$ day 2 & $81.70 \pm 0.77^{\mathrm{ab}}$ & $86.72 \pm 0.59^{\mathrm{a}}$ & $14.45 \pm 0.53^{\mathrm{cd}}$ \\
$\mathrm{RC}$ day 3 & $80.24 \pm 3.31^{\mathrm{ab}}$ & $86.02 \pm 1.01^{\mathrm{a}}$ & $15.21 \pm 2.43^{\mathrm{cd}}$ \\
$\mathrm{RC}$ day 4 & $79.32 \pm 1.60^{\mathrm{ab}}$ & $85.01 \pm 0.41^{\mathrm{a}}$ & $16.42 \pm 1.15^{\mathrm{cd}}$ \\
$\mathrm{RC}$ day 5 & $78.22 \pm 1.30^{\mathrm{ab}}$ & $85.01 \pm 1.30^{\mathrm{a}}$ & $15.78 \pm 2.66^{\mathrm{cd}}$ \\
$\mathrm{RC}$ day 6 & $79.77 \pm 2.09^{\mathrm{ab}}$ & $83.15 \pm 2.64^{\mathrm{ab}}$ & $16.83 \pm 1.70^{\mathrm{cd}}$ \\
$\mathrm{RC}$ day 7 & $77.49 \pm 2.19^{\mathrm{b}}$ & $82.19 \pm 2.68^{\mathrm{ab}}$ & $17.94 \pm 1.24^{\mathrm{c}}$ \\
\hline
\end{tabular}

Table 3. color value of the middle section during storage in each treatment

\begin{tabular}{cccc}
\hline Treatment & $\mathrm{L}^{*}$ & $\mathrm{~h}$ & $\mathrm{C}^{*}$ \\
\hline Control & $81.85 \pm 3.33^{\mathrm{bc}}$ & $93.85 \pm 1.33^{\mathrm{a}}$ & $18.28 \pm 2.06^{\mathrm{ab}}$ \\
AC day 2 & $78.09 \pm 0.87^{\mathrm{c}}$ & $87.14 \pm 2.57^{\text {cde }}$ & $18.12 \pm 2.49^{\mathrm{ab}}$ \\
AC day 3 & $83.23 \pm 1.40^{\mathrm{ab}}$ & $90.67 \pm 1.67^{\mathrm{b}}$ & $15.98 \pm 1.95^{\mathrm{bc}}$ \\
AC day 4 & $77.48 \pm 1.28^{\mathrm{c}}$ & $85.80 \pm 1.47^{\mathrm{e}}$ & $20.93 \pm 2.72^{\mathrm{a}}$ \\
RC day 2 & $80.38 \pm 0.98^{\mathrm{ab}}$ & $89.38 \pm 2.34^{\mathrm{bcd}}$ & $12.69 \pm 0.34^{\mathrm{c}}$ \\
RC day 3 & $84.14 \pm 0.47^{\mathrm{a}}$ & $90.15 \pm 0.50^{\mathrm{bc}}$ & $13.06 \pm 2.04^{\mathrm{c}}$ \\
RC day 4 & $84.27 \pm 0.73^{\mathrm{a}}$ & $89.27 \pm 1.33^{\mathrm{bcd}}$ & $12.13 \pm 0.94^{\mathrm{c}}$ \\
RC day 5 & $82.36 \pm 1.62^{\mathrm{ab}}$ & $89.48 \pm 2.47^{\mathrm{bcd}}$ & $14.91 \pm 3.80^{\mathrm{bc}}$ \\
RC day 6 & $80.25 \pm 1.46^{\mathrm{bc}}$ & $86.39 \pm 0.72^{\mathrm{de}}$ & $18.68 \pm 0.82^{\mathrm{ab}}$ \\
RC day 7 & $82.60 \pm 3.32^{\mathrm{ab}}$ & $87.94 \pm 1.46^{\mathrm{bcde}}$ & $14.03 \pm 5.20^{\mathrm{bc}}$ \\
\hline
\end{tabular}

$\mathrm{AC}=$ Ambient condition; $\mathrm{RC}=$ Refrigerated condition. All values are means \pm standard deviation $(\mathrm{n}=3)$. Different superscripts in the same column indicates significant difference $(\mathrm{p}<0.05)$.

Table 4. Firmness of the basal and middle section of shoot during storage in each treatment

\begin{tabular}{|c|c|c|}
\hline \multirow{2}{*}{ Treatment } & \multicolumn{2}{|c|}{ Firmness $(\mathrm{N})$} \\
\hline & Basal section & Middle section \\
\hline Control & $12.39 \pm 0.97^{\mathrm{cd}}$ & $8.28 \pm 1.10^{\mathrm{ab}}$ \\
\hline AC day 2 & $15.22 \pm 0.10^{\mathrm{a}}$ & $7.50 \pm 0.16^{\mathrm{bc}}$ \\
\hline AC day 3 & $14.79 \pm 2.98^{\mathrm{ab}}$ & $8.73 \pm 0.85^{\mathrm{ab}}$ \\
\hline AC day 4 & $13.01 \pm 0.39^{\mathrm{bc}}$ & $8.90 \pm 0.87^{\mathrm{a}}$ \\
\hline $\mathrm{RC}$ day 2 & $11.03 \pm 0.35^{\mathrm{cd}}$ & $6.12 \pm 0.28^{\mathrm{d}}$ \\
\hline $\mathrm{RC}$ day 3 & $10.23 \pm 0.35^{\mathrm{d}}$ & $6.79 \pm 0.87^{\mathrm{cd}}$ \\
\hline RC day 4 & $12.12 \pm 0.17^{\mathrm{cd}}$ & $8.41 \pm 0.44^{\mathrm{ab}}$ \\
\hline RC day 5 & $10.83 \pm 0.58^{\mathrm{cd}}$ & $6.86 \pm 0.73^{\mathrm{cd}}$ \\
\hline RC day 6 & $11.54 \pm 1.06^{\mathrm{cd}}$ & $7.72 \pm 0.13^{\mathrm{abc}}$ \\
\hline $\mathrm{RC}$ day 7 & $12.63 \pm 0.38^{c}$ & $7.67 \pm 0.26^{\mathrm{abc}}$ \\
\hline
\end{tabular}

Table 5. Total acid (\%) and reducing sugar content of shoot during storage in each treatment

\begin{tabular}{ccc}
\hline Treatment & Total acid (\%) & $\begin{array}{c}\text { Reducing sugar } \\
\text { content }(\mathrm{g} / \mathrm{L})\end{array}$ \\
\hline Control & $0.069 \pm 0.004^{\mathrm{e}}$ & $52.42 \pm 3.32^{\mathrm{a}}$ \\
AC day 2 & $0.129 \pm 0.312^{\mathrm{a}}$ & $20.25 \pm 0.50^{\mathrm{e}}$ \\
AC day 3 & $0.123 \pm 0.379^{\mathrm{a}}$ & $19.21 \pm 0.29^{\mathrm{e}}$ \\
AC day 4 & $0.129 \pm 0.050^{\mathrm{a}}$ & $17.21 \pm 1.38^{\mathrm{e}}$ \\
RC day 2 & $0.089 \pm 0.001^{\mathrm{cd}}$ & $43.08 \pm 0.76^{\mathrm{b}}$ \\
RC day 3 & $0.107 \pm 0.005^{\mathrm{b}}$ & $42.08 \pm 2.75^{\mathrm{b}}$ \\
RC day 4 & $0.107 \pm 0.005^{\mathrm{b}}$ & $40.92 \pm 2.08^{\mathrm{bc}}$ \\
RC day 5 & $0.098 \pm 0.001^{\mathrm{cd}}$ & $33.71 \pm 0.29^{\mathrm{d}}$ \\
RC day 6 & $0.065 \pm 0.005^{\mathrm{cd}}$ & $35.29 \pm 1.42^{\mathrm{d}}$ \\
RC day 7 & $0.084 \pm 0.002^{\mathrm{d}}$ & $38.38 \pm 1.56^{\mathrm{c}}$ \\
\hline
\end{tabular}

$\mathrm{AC}=$ Ambient condition; $\mathrm{RC}=$ Refrigerated condition. All values are means \pm standard deviation $(\mathrm{n}=3)$. Different superscripts in the same column indicates significant difference $(\mathrm{p}<0.05)$.

Table 6. Proximate composition of the bamboo shoot during storage in each treatment (percentage)

\begin{tabular}{ccccccc}
\hline Treatment & Moisture & Protein & Fat & Fiber & Carbohydrate & Ash \\
\hline Control & $91.85 \pm 0.20$ & $1.99 \pm 0.31$ & $0.92 \pm 0.02$ & $0.92 \pm 0.08$ & $3.63 \pm 0.22$ & $0.68 \pm 0.06$ \\
AC day 4 & $92.77 \pm 0.19$ & $2.74 \pm 0.52$ & $0.77 \pm 0.04$ & $1.01 \pm 0.01$ & $1.87 \pm 0.30$ & $0.84 \pm 0.03$ \\
RC day 4 & $92.56 \pm 0.19$ & $1.85 \pm 0.73$ & $0.61 \pm 0.03$ & $0.71 \pm 0.04$ & $3.62 \pm 0.30$ & $0.65 \pm 0.03$ \\
RC day 7 & $92.70 \pm 0.21$ & $1.80 \pm 0.05$ & $0.03 \pm 0.01$ & $0.72 \pm 0.06$ & $3.79 \pm 0.13$ & $0.95 \pm 0.11$ \\
\hline
\end{tabular}

$\mathrm{AC}=$ Ambient condition; $\mathrm{RC}=$ Refrigerated condition. Moisture content is expressed as \% wet basis. All values are means \pm standard deviation $(\mathrm{n}=3)$ 
refrigerated sample was not significantly different from the control $(p>0.05)$. The firmness of the middle section of the refrigerated sample slightly decreased after storage for 3 days and was not significantly different $(p>0.05)$ through the period of storage. Luo et al. (2008) reported that shoot firmness, lignin and cellulose increased and accelerated by higher storage temperature and there was a positive correlation between them and low temperature is an effective method for delaying lignification of bamboo shoot.

\subsection{Total acidity, sugar content and proximate analysis}

Total acidity and reducing sugar content are shown in Table 5. Total acidity of all sample was significantly increased after 2 days of storage $(p<0.05)$. The increasing rate of total acidity of the ambient sample was higher compared to the results of total acidity of refrigerated storage. The reducing sugar content of ambient samples decreased more than $50 \%$ from the control while the refrigerated sample decreased only $17.81 \%$. The low sugar content and high acidity could effect to shoot flavor and lead to low customer acceptance (Xia, 2006). Thammawong et al. (2009) revealed that not only storage time effected to the total sugar content of bamboo shoot but also different maturity. Underground bamboo shoots which newly sprouted has higher sugar content comparison with emerged shoots. $\mathrm{Lu}$ and $\mathrm{Xu}$ (2004) found that the reducing sugar of the basal rapidly decreased during the first 10 days of storage while apical sections declined slightly at the beginning of the storage.

The proximate analysis of the bamboo shoots is shown in Table 6. Moisture content is an important factor in fresh shoots, all treatments were moisture content over $90 \%$ (wet basis) and not different due to temperature and duration storage. In the 4 days of storage, the content of protein, fiber and ash composition of ambient samples increased while fat and carbohydrate content decreased. By the way, the amount of moisture and fiber content were not different from the control. Protein, fat and fiber contents of refrigerated samples deceased from 4 days to 7 days storage but carbohydrate and ash content increased during this period. It could be said that temperature and storage period effect to nutrient degradation and these were the beginning of a shoot deterioration. This result was in agreement with Zhang et al. (2017), reported that storage temperature and time were important factors which effected on nutrients and the storage in low temperature could maintain a high level of nutritive constituents compared with storage in room temperature. Moreover, Ding et al. (1997), Ding et al. (2006) and Song et al. (2013) reported that temperature plays as a major role in causing senescence of agriculture product.

\subsection{Sensory evaluation}

The 9 -Point hedonic scale test was acquired for the evaluation of consumer acceptance toward stored bamboo shoot conditions. Overall liking, appearance, color and odor of the samples were evaluated. The results are shown in Table 7 . It can be seen that, on the first day of harvested shoots, the consumer evaluated the sample from like moderately to like very much (7-8 points). After one day of storage, the hedonic scores of all attributes of ambient condition sample decreased to neither like nor dislike to slightly like (5-6 points) and were significantly different from the control $(p<0.05)$. The scores of ambient condition sample continuously reduced to slightly dislike to neither like nor dislike (4-5 points) after 3 days. While the hedonic scores of most attributes of refrigerated condition sample were still slightly like to like moderately (6-7 points) during storage and only odor factor was significantly different from the control $(p<0.05)$. After 2 days of storage, color and odor scores of ambient condition sample were lower than 5 which can be considered as a level to decide that this food in unacceptable for the consumer (Grosso and

Table 7. Sensory evaluation of the bamboo shoot during storage in each treatment

\begin{tabular}{ccccc}
\hline Treatment & Color & Appearance & Odor & Overall liking \\
\hline Control & $7.86 \pm 0.96^{\mathrm{a}}$ & $7.60 \pm 1.25^{\mathrm{a}}$ & $7.93 \pm 0.85^{\mathrm{a}}$ & $7.66 \pm 1.07^{\mathrm{a}}$ \\
AC day 2 & $5.40 \pm 1.54^{\mathrm{c}}$ & $5.40 \pm 1.36^{\mathrm{b}}$ & $5.66 \pm 1.25^{\mathrm{cd}}$ & $5.93 \pm 1.53^{\mathrm{b}}$ \\
AC day 3 & $5.00 \pm 1.37^{\mathrm{c}}$ & $5.40 \pm 1.40^{\mathrm{b}}$ & $4.86 \pm 1.15^{\mathrm{de}}$ & $5.33 \pm 1.49^{\mathrm{b}}$ \\
AC day 4 & $4.93 \pm 1.54^{\mathrm{c}}$ & $5.13 \pm 1.59^{\mathrm{b}}$ & $4.53 \pm 1.02^{\mathrm{f}}$ & $5.06 \pm 1.70^{\mathrm{b}}$ \\
RC day 2 & $7.21 \pm 0.77^{\mathrm{ab}}$ & $7.26 \pm 1.18^{\mathrm{a}}$ & $7.33 \pm 0.94^{\mathrm{bc}}$ & $7.33 \pm 0.87^{\mathrm{a}}$ \\
RC day 3 & $7.13 \pm 0.72^{\mathrm{ab}}$ & $7.20 \pm 0.65^{\mathrm{a}}$ & $6.46 \pm 0.81^{\mathrm{b}}$ & $7.06 \pm 0.57^{\mathrm{a}}$ \\
RC day 4 & $7.20 \pm 0.91^{\mathrm{ab}}$ & $6.93 \pm 0.93^{\mathrm{a}}$ & $6.86 \pm 0.96^{\mathrm{b}}$ & $7.00 \pm 0.89^{\mathrm{a}}$ \\
RC day 5 & $7.06 \pm 1.29^{\mathrm{ab}}$ & $6.93 \pm 1.12^{\mathrm{a}}$ & $6.86 \pm 1.45^{\mathrm{b}}$ & $6.93 \pm 1.18^{\mathrm{a}}$ \\
RC day 6 & $7.00 \pm 1.21^{\mathrm{ab}}$ & $6.86 \pm 1.20^{\mathrm{a}}$ & $6.80 \pm 1.28^{\mathrm{b}}$ & $6.93 \pm 1.39^{\mathrm{a}}$ \\
RC day 7 & $6.93 \pm 1.00^{\mathrm{b}}$ & $6.86 \pm 0.88^{\mathrm{a}}$ & $6.80 \pm 1.11^{\mathrm{b}}$ & $6.93 \pm 1.06^{\mathrm{a}}$ \\
\hline
\end{tabular}

$\mathrm{AC}=$ Ambient condition; $\mathrm{RC}=$ Refrigerated condition. All values are means \pm standard deviation $(\mathrm{n}=3)$. Different superscripts in the same column indicates significant difference $(p<0.05)$. 
Resurreccion, 2002). It can be told that consumers accepted the shoot which kept ambient temperature storage for 1 or 2 days while the refrigerated shoot could be kept for 7 days. The appearance of the basal section was the first impression and important quality parameter judged by consumer. The darker color of basal shoot effected on quality and shelf life of bamboo shoot, but the color of the middle shoot was still white-yellow color throughout the shelf life.

\section{Conclusion}

In this study, the important deterioration factors of the bamboo shoot were color, odor and decreasing sugar content which related to consumer acceptance. The shelf life of bamboo shoot at ambient temperature was 1 day due to the brown color of the basal section and the sugar content gradually decreased to approximately $50 \%$. The shoots kept in refrigerated condition could be stored at least for 7 days. The low sugar content and high acidity could affect to fresh shoot flavor together with discoloration of basal shoot led to low customer acceptance. So, the possible quality indicators of the bamboo shoot after harvesting could be color and odor for the commercial launched product because of easily recognized by sight.

\section{Conflict of Interest}

The authors declared no conflict of interest.

\section{Acknowledgments}

The authors thank Pibulsongkram Rajabhat University for research funding with a project grant number RDI-4-61-18.

\section{References}

AOAC. (2000). Official Methods of Analysis, $6^{\text {th }}$ ed. Gaithersburg, Maryland: USA: AOAC International

Chen, R.Y., Liu, M.S., Chang, T.C. and Tsai, M.J. (1989). Postharvest Handling and Storage of Bamboo Shoot (Bambusa oldhami Munro). Acta Horticulturae, 258, 309-316. https:// doi.org/10.17660/ActaHortic.1989.258.35

Clark, L. (2012). An Updated Tribal and Subtribal Classification of the Bamboos (Poaceae: Bambusoideae), Presented at 9th World Bamboo Congress. USA: World Bamboo Organization.

Ding, C.K., Chachin, K., Ueda, Y. and Mochika, M. (1997). Effect of Cold Storage and Harvest Ripeness on the Quality and Chemical Composition of Loquat Fruits. Food Science and Technology International, Tokyo, 3(2), 200-204. https://doi.org/10.3136/

\section{fsti9596t9798.3.200}

Ding, Z., Tian, S., Wang, Y., Li, B., Chan, Z., Han, J. and $\mathrm{Xu}, \mathrm{Y}$. (2006). Physiological Response of Loquat Fruit to Different Storage Conditions and Its Storability. Postharvest Biology and Technology, 41 (2), 143-150. https://doi.org/10.1016/ j.postharvbio.2006.03.012

Grosso, N.R. and Resurreccion, A.V.A. (2002). Predicting Consumer Acceptance Ratings of Cracker -coated and Roasted Peanuts from Descriptive Analysis and Hexanal Measurements. Journal of Food Science, 67(4), 1530-1537. https:// doi.org/10.1111/j.1365-2621.2002.tb10317.x

Kleinhenz, V., Gosbee, M., Elsmore, S., Lyall, T.W., Blackburn, K., Harrower, K. and Midmore, D.J. (2000). Storage Methods for Extending Shelf Life of Fresh, Edible Bamboo Shoots [Bambusa oldhamii (Munro)]. Postharvest Biology and Technology, 19 (3), 253-264. https://doi.org/10.1016/S0925-5214 (00)00094-6

Kusalaruk, W. and Limsangouan, H. (2015). Nutrition and Nutraceutical of Bambusa burmanica Gamble and Thysostachys siamensis Gamble shoots. Thai Agricultural Research Journal, 33(2), 169-178.

$\mathrm{Lu}$, S.M. and Xu, Y.G. (2004). Physiological and Biochemical Changes of Fresh-cut Bamboo Shoot (Phyllostachys heterocycle var pubescens) during Cold Storage. Journal of the Science of Food and Agriculture, 84(8), 772-776. https://doi.org/10.1002/ jsfa. 1725

Luo, Z., Xu, X. and Yan, B. (2008). Accumulation of Lignin and Involvement of Enzymes in Bamboo Shoot during Storage. European Food Research and Technology, 226(4), 635-640. https:// doi.org/10.1007/s00217-007-0595-y

Mahayotpanya, Ch. And Phoungchandang, S. (2015). Study of Physical and Chemical Properties and Desorption Isotherms for Bamboo Shoots (Dendrocalamus asper Backer), Presented at 34th National Graduate Research Conference. Khonkaen, Thailand: Khonkaen University Publishing.

Nugrahedi, P.Y., Lusiani, M. and Persijin, S.T. (2004). Effect of Modified Atmosphere Packing on Selected Phenomena Affecting Quality of Fresh, Edible Bamboo Shoots. Indonesian Food and Nutrition Progress, 11(1), 20-24.

Peryam, D.R. and Pilgrim, F.J. (1957). Hedonic Scale Method of Measuring Food Preferences. Food Technology, 11, 9-14.

Phuanchik, T., Ruensuk, P. and Jirakiattikul, Y. (2015). Study on Growth of Four Bamboo Varieties. Thai Journal of Science and Technology, 4(3), 302-309. 
Shen, Q., Kong, F. and Wang Q. (2006). Effect of Modified Atmosphere Packing on the Browning and Lignification of Bamboo Shoots. Journal of Food Engineering, 77(2), 348-354. https:// doi.org/10.1016/j.jfoodeng.2005.06.041

Shukla, R., Sumit, G., Dwivedi, P.K. and Mishra, A. (2012). Medicinal Importance of Bamboo. International Journal of Biopharm and Phytochemical Research, 1(1), 9-15.

Sindhal, P., Bal, L.M., Satya, S., Sudhakar, P. and Naik, S.N. (2013). Bamboo Shoots: a Noval Source of Nutrition and Medicine. Critical Reviews in Food Science and Nutrition, 53(5), 517-534. https:// doi.org/10.1080/10408398.2010.531488

Song, L., Chen, H., Gao, H., Fang, X., Mu, H., Yuan, Y., Yang, Q. and Jiang, Y. (2013). Combined Modified Atmosphere Packing and Low Temperature Storage Delay Lignification and Improve the Defense Response of Minimally Processed Water Bamboo Shoot. Chemistry Central Journal, 7(1), 1-9. https:// doi.org/10.1186/1752-153X-7-147

Sood, S., Walia, S. and Sood, A. (2017). Quality Evaluation of Different Species of Edible Bamboo Shoots. ARC Journal of Nutrition and Growth, 3(1), 1-6. https://doi.org/10.20431/2455-2550.0301001

Thammawong, M., Nei, D., Roy, P., Nakamura, N. and Shiing, T. (2009). Characteristics of Sugar Content in Different Sections and Harvest Maturity of Bamboo Shoots. HortScience, 44(7), 1941-1946. https://doi.org/10.21273/HORTSCI.44.7.1941

Teerapapthamkul, S., Tongpo, S., Jamsri, V., Promprasit, P., Unahalekhaka, J. and Chinwattanawong, P. (2011). Risk Assessment of Cyanide in Bamboo Shoots of Thai Consumer. Bulletin of the Department of Medical Sciences, 53(2), 67-69.

Xia, B. (2006). Studies on Nutrient and Chemical Components of Shoots of Arundinaria oleosa. China: Nanjing Forestry University, MSc. Dissertation.

Xu, Y.G., Lu, S.M. and Wang, Q. (2004). Changes of Cell Wall Components and PAL Activity in Freshcut Bamboo Shoots during Cold Storage. Journal of Food Biochemistry, 28(2), 167-177. https:// doi.org/10.1111/j.1745-4514.2004.tb00063.x

Zhang, W.E., Wang, C.L., Shi, B.B. and Pan, X.J. (2017). Effect of Storage Temperature and Time on the Nutritional Quality of Walnut Male Inflorescences. Journal of Food and Drug Analysis, 25(2), 374-384. https://doi.org/10.1016/ j.jfda.2016.05.010

Zhou, J., Zhang, G., Hu, H. and Wang, Z. (2012). Effect of Packaging Materials on the Shelf Life of Bamboo
Shoots. Applied Mechanics and Materials, 200, 540544. https://doi.org/10.4028/www.scientific.net/ AMM.200.540 